\title{
Markedness in Writing: A Case of EFL Students
}

\author{
Seyed Foad Ebrahimi \\ Department of English, Shadegan Branch, Islamic Azad University, Shadegan, Iran \\ Email: seyedfoade@yahoo.com \\ Seyed Jamal Ebrahimi \\ Department of English, Shadegan Branch, Islamic Azad University, Shadegan, Iran \\ Email: Jetco2003@yahoo.co.uk
}

\begin{abstract}
Theme is the element which serves as the point of departure of the message; it is that which the clause is concerned (Halliday, 1994). One of the themes in Halliday's (1994) model is marked theme in which there are some elements put in the theme position that frequently indicate notions such as validation of internal evidence; location in discourse time/space and writer viewpoint (Davies, 1989 as cited in Gosden, 1992). Such fronted elements, often at sentence boundaries, commonly have the function of textual organization by signaling changes and turns in real-world and discourse circumstances. This study made frequency and functional analysis of marked theme used in students' composition writings. This study was carried out on the corpus of 180 compositions come from narrating three pictorial by sixty students- 20 sophomore, 20 junior, and 20 senior- majoring in Teaching English as Foreign Language. Students narrated these stories in three sessions of 45 minutes. The gathered data, 180 compositions, were analyzed in terms of marked theme based on Halliday's (1994) model of thematic organization. The results illustrated significant differences between the three groups regarding their use of marked theme.
\end{abstract}

Index Terms - marked theme, thematic organization, academic experience

\section{INTRODUCTION}

In EFL context, reading and writing are the two skills used for getting and producing language. Writing as channel of producing language has always been problematic for both teachers to teach and students to learn. According to Gabrielatos (2002) writing is of two levels: language and organization. In former level, the focus is on grammar and vocabulary used in the sentences. In the later level, lay out, punctuation, and method of organization are the concerns. EFL teachers spends most of their time on the language level by checking the students' writings for grammatical and vocabulary errors, and neglecting the organizational level. By staying at the sentence level, EFL teachers can't help the students to produce cohesive texts in which the sentences are well organized and well connected, because what comes first for students is to make grammatically correct sentences by using suitable words. By teaching writing in this way, the problem of writing cohesive and well-organized paragraphs will not be solved.

One way of achieving well-organized and cohesive text is through thematic patterning, proposed by systemic functional grammar. (Belmonte and MacCabe, 1998).

Systemic Functional Grammar and Theme

In Halliday and Mathiessen's word, grammar is part of language that can be interpreted from different viewpoints. In one view, language is a set of rules to specify structures; so, grammar as a subsystem of language is also a set of rules that specifies grammatical structures. In the other view, language is a resource that can create meaning through wording (1997, p. 1). Systemic functional grammar theory associated with the school of linguistics was first developed in the work of the grammar of Chinese and used in educational and computational contexts. Unlike the grammatics that is usually presented in school, "systemic-functional grammatics takes the resource perspective rather than the rule perspective" and shows "the overall system of grammar rather than only fragments" (Halliday \& Mathiessen, 1977, p. 2).

In systemic functional grammar, the main focus is on clause, and as Halliday $(1994$, p. 19) states, the mode of interpretation in this approach is functional in which the grammatical structure is being explained referring the meaning and there is a general principle in language that larger units act more directly in the realization of higher-level patterns .

In the existing literature in Systemic Functional, researchers consider clause as made by a combination of three metafunctions (Halliday, 1985; Halliday \& Mathiessen, 1997; Martin \& Rose, 2007; Ping, 2003). These three metafunctions are as follows:

1. Interpersonal metafunction: Martin and Rose (2007) point out that interpersonal metafunction "is concerned with negotiation of social relations: How people are interacting, including the feelings they try and share" (p. 24). Halliday and Mathiessen (1997) emphasize that one of the major grammatical systems of this kind of metafunction is mood, the grammaticalization of speech function (p. 11).

2. Ideational metafunction: Martin and Rose (2007) say that ideational metafunction "is concerned with construing experience: What's going on, including who's doing what to whom, where, when, why, how, and the logical relation of 
one going on to another" (p. 24). In Halliday and Mathiessen's viewpoint, transitivity, "the resource for construing our experience the flux of 'goings-on', as structural configurations, each consisting of a process, the participants involved in the process, and circumstances attendant on it, is one of major ideational metafunction's grammatical systems (1997, p. 11). As Halliday (1994) states, "transitivity structures express representational meaning: what the clause is about, which is typically some process, with associated participants and circumstances" (p. 179).

3. Textual metafunction: As Martin and Rose (2007) mention, textual metafunction "is concerned with information flow: The ways in which ideational and interpersonal resources are distributed in waves of semiosis, including interconnections among waves and between language and attendant modalities" (p. 24). Halliday and Mathiessen (1997) argue that theme is one of the major textual systems. It is the resource to set up a local context for a clause by selecting a local point of departure in the flow of information (p. 11).

Davidse (1987) argues that these metafunctions are both intrinsic and extrinsic to language. In the first place, they are separate components, or semantic organizing principles, of the grammar. But the ideational and interpersonal functions also finally refer to social reality. They represent the social uses to which language is put (p. 51). He also asserts that the metafunctions are a key concept in Halliday's theory since they explain the internal organization of language and are systematically related to the register variables of field, tenor, and mode (p. 57).

Matthiessen (2004) also mentioned that the textual mode of expression is based on degree of prominence. Prominence may be considered in one of three ways: 1) positionally by means of culminative placement at the beginning or the end of the clause; 2) segmentally by means of some prominence marker that emphasizes one element out of the other elements of the clause; 3 ) intonationally by means of tonic prominence (p. 549).

In Halliday and Mathiessen's (1997) mind, the textual metafunction-which, as stated by Gosden (1992), is manifested as theme in the clause- engenders resources for presenting interpersonal and ideational meanings as information organized into text that can be on goingly exchanged between producer and receiver. This involves transitions in the development of text (conjunctive relations) and the assignment of different textual statuses. These transitions and statuses enable the exchange of information; the producer is guiding the receiver in interpreting the unfolding text (p. 19).

Halliday (1985, p. 30) defines theme as an element which serves as the point of departure of the message and what the speaker has in mind to start with. It is the element in a particular structural configuration taken as whole, and it organizes the clause as a message. The remainder of the message is called the rheme. Therefore, a clause consists of a theme combined with a rheme and the structure is expressed by order. The order for this is theme followed by rheme. In the same line, Brown and Yule (1983) stated that one of the constraints on the speakers /writers is that they can produce only one word at a time when they are producing their messages. They have to choose a beginning point for their utterances in order to organize their messages. The initial point is important in the clause and also in the discourse. It influence the hearers/readers' interpretation of every thing that follows in the discourse since it constitute the initial textual context for everything that follows. What is placed in this initial position is called theme.

Fries (1992) also pointed out that both native and non-native English speaking students have difficulty ordering the words in their sentences. What is the difference between sentences such as (1) and (2):

1. They left their examination on the table yesterday.

2. Yesterday they left their examination on the table.

Clearly, the answer doesn't lie in the words being described in the two sentences but rather in the way that words are presented. We can say roughly that "yesterday" received focal attention in sentence (1), while "on the table" received focal attention in sentence (2). By the same token in these sentences, they set up a context in which the reminder of the sentence is to be interpreted. Words like "they" and "yesterday" which serve an orienting function are called theme.

The notion of thematicity has caught the eyes of many researchers during recent years. Most have addressed this issue across such different languages (Ventola, 1993; Jalilifar \& Khedri, 2011); various disciplines (Whittaker, 1995; Ghadessy, 1999); within discipline (Martinez, 2003; Lores, 2004; Jalilifar, 2010); essay writing (North, 2005); and composition writing (Wang, 2007; Ebrahimi, 2008). Yet, despite a sustained interest in thematicity, little research has examined the use of theme in students' composition writings and its possible influences on the texts. One notable exception is Wang's (2007) study of the relationship between theme and rheme in the academic texts and in improving the textual cohesion in students' writing. The other exception is North (2005), which analyzed essays written by students from different backgrounds using systemic functional approach.

This scarcity is felt more when it comes to marked theme in EFL academic contexts. Therefore, bearing the important essence of theme; the crucial role that it plays in writing well-organized texts; and also extremely low done studies in this area of research in mind, this study aims to scrutinize the status of marked theme (one of the theme types proposed by Halliday, 1994) in EFL students' composition writings taking their academic experience into consideration.

\section{METHOD}

\section{A. Corpus}

This study was carried out on the corpus of 180 compositions written based on three pictorial stories by 60 EFL students- 20 sophomore, 20 junior, and 20 senior- majoring in Teaching English as Foreign Language (TEFL). 
Sophomore students have received 128 hours instruction on English language grammar. Junior students beside the instruction on grammar, they have received 32 hours instruction on paragraph writing. Senior students beside the instructions on the grammar and paragraph writing, they have received 32 hours instruction on essay writing. To make sure about the homogeneity of the students within the three groups, they were given a test of homogeneity (Fowler $\&$ Coe 1976) and the average score of each group was above 70 percent.

\section{B. Instruments and Materials}

1) Three pictorial stories were used for data gathering. The rationale for selecting these pictorial stories was to control students' writing by giving the same ideas to them for writing composition. Three stories were assigned in order to check the use of marked theme in more than one context and to minimize the influence of single context on students' writing simultaneously; 2) To put the participants into appropriate levels, they were asked to take three homogeneity tests (Fowler \& Coe, 1976). 3) And, in order to achieve a well-organized study, complete model is required for analyzing the data. To do this, Halliday's (1994) model of thematic organization was applied. The major rationale behind the selection of his model was twofold: 1) as Martinez (2003, p. 108) mentions, this model provides plausible and attestable mechanisms for determining the thematic structures of the texts correctly; 2) it is practical, reliable, and up-to-date model. Most of the studies that have been done in terms of thematic analysis have resorted to this model.

\section{Procedure}

At first, 90 students, (30 by each group), were selected and set for homogeneity test (Fowler \& Coe, 1976) based on their academic experience. At the same time, their scores on English language grammar, paragraph writing, and essay writing were collected from the examination department. Students whose score in the homogeneity test and their average score on their courses was also above 70 percent were chosen for this study. To have equal number of students in each group, the top 20 students from each level were selected.

Second, after meeting the homogeneity in the groups, three pictorial stories were given to students to narrate. The stories only included some pictures without any caption or description given by the researcher and supposed to be narrated in three sessions of 45 minutes. Finally, the gathered data were analyzed based on Halliday's (1994) model of thematic organization and in order to check the significance of the differences between the groups regarding their use of marked theme, Chi-square was run on the data.

One problem with text analysis is that there is always the danger of making mistakes in interpretation. To increase the reliability in the analysis, nine compositions from the corpus were also analyzed by an experienced researcher in applied linguistics and agreement was made on the method of analysis.

\section{Unit of Analysis}

This study adopted t-unit as the basic unit of analysis. T-unit is defined by Fries (1994) as a clause complex which contains one main independent clause together with all the hypotactic clauses which are dependent on it. The rationale behind this selection was that:

Analyzing theme at the level of t-unit rather than the individual clause makes it easier to focus on patterns of thematic development in large amounts of text, and can also be justified on the grounds that the thematic structure of a dependent clause is often constrained by the independent clause. (Fries \& Francis, 1992 as cited in North, 2005).

\section{RESULT AND DISCUSSION}

\section{Marked Theme in EFL Students' Writings}

In all the three groups, marked theme was underestimated and used in small number. This result was comparable with Whittaker's (1995), Ghadessy's (1999), and MacCabe's (1999) findings, and in contrast with North's (2005), and Coffin and Hewings (2005) findings. Coffin and Hewings (2005) found (18.82\%) marked themes in the students' writings (p.158). North (2005), in her study of thematicity in essay writing, found that (17.08\%) of the topical themes was marked (p.11). This opposed the findings of the present study, where at most $(9.90 \%)$ of themes was marked. The gained result indicates that most of the topical themes occupy both thematic and subject positions. Theme/subject compliance may also be indicative of structural simplicity of students' writings with different academic experience. The low portion of the marked themes in students' writings shows that students' writing is less argumentative in nature. Students in all the three groups allocated somehow identical percentages of all the theme types to marked theme. This similarity can be explained in terms of genre.

According to Halliday and Hasan (1976), texts belonging to the same genre represent a similar contextual configuration, that is, they show common characteristics in terms of field, mode, and tenor of discourse (p.46). As far as composition writing patterns the same family of genre, then this similarity in students' composition is not surprising.

So similarities in field, tenor, and mode engender similarities in textual choices and are reflected in the thematic choices preferred since the field, tenor, and mode can be realized in theme. Therefore, theme as one of the textual choices provides interesting insight into establishing similarities within and between genres. This is inline with other studies like Ghadessy's (1999), North's (2005), Ghadessy's (1995), and Whittakar's (1995) findings. These researchers suggested that different types of theme can reveal crucial characteristics of the texts regarding genre. 
The result of chi-square analysis displayed interesting point regarding marked theme use in by the three groups. The analysis figured out that there is a systematic increase in the use of marked theme moving from sophomore to senior group.

There higher use of marked theme in senior group may suggest that senior students could distinguish between the definition and position of the theme. Halliday (1985) asserts that theme can be identified as that element which comes in the first position in the clause, but this is not how the category of theme defined. The definition is functional, as it is with all the elements in this interpretation of grammatical structure. Theme is one element in a particular structural configuration which, taken as a whole, organizes the clause as a message. Senior students in contrast to other two groups put those elements that organize the text as message in the theme position.

The discourse function of marked theme could be one reason behind its over-use by senior students. Looking at marked theme from functional view point, these students used this theme to put some elements that frequently indicate notions such as validation of internal evidence, location in discourse time or space, and writer view points into the theme position (Davies, 1989 as cited in Gosden, 1992). These elements, often at sentences boundaries, commonly have the function of textual organization, like signaling changes and turns in real world and discourse circumstances. It is recognition of these internal signals that help identify the rhetorical moves outlined by Swales (1981, 1990) (Gosden, 1992)

The small number of marked theme in sophomore group may be rooted in that these students, in this study, prefer to place theme in the subject position of the clause. By doing so, these students could make sure that their sentences are grammatically correct. This is the simple way of constructing canonical English sentences that follow NP VP pattern. They may think that English has a fixed word order and they need to be provided with sufficient input with different word orders by their teachers. They must be familiar with, that fronting as a powerful recourse to highlight adverbial or objects and that this fronting acts as the organizer of information in the sentence.

TABLE 1

MARKED THEME IN STUDENTS' WRITING

\begin{tabular}{|c|c|c|c|c|c|c|}
\hline & \multicolumn{2}{|c|}{ SOPHMRE (\%) } & JUNIOR(\%) & \multicolumn{3}{|c|}{ SENIOR $(\%)$} \\
\hline MRKED & \multicolumn{2}{|c|}{$121(9.05)$} & $155(9.10)$ & \multicolumn{2}{|c|}{$197(9.90)$} & \\
\hline \multicolumn{7}{|c|}{$\begin{array}{c}\text { TABLE } 2 \\
\text { CHI-SQUARE ANALYSIS OF MARKED THEME IN STUDENTS' WRITING }\end{array}$} \\
\hline & SOPHMRE (\%) & JUNIOR $(\%)$ & SENIOR $(\%)$ & CHI-SQUARE VALUE & $\mathrm{DF}$ & SIG. \\
\hline MRKED & $121(9.05)$ & $155(9.10)$ & $197(9.90)$ & 18.380 & 2 & 0.000 \\
\hline
\end{tabular}

\section{CONCLUSION}

In EFL writing context, we often find that learners write compositions made of sentences and paragraphs which do not have textual organization. This results in creating a fuzzy text and finally getting the reader into trouble. They may not be aware of such cohesive devices as theme/rheme structures to focus on. Consequently, they will succeed, to some extent, in displaying the unfolding of the global structure of the text.

Bearing such a problem in mind, the aim of this study was to find out the marked theme used in EFL students' composition writings, and its possible relation to the students' academic experience. The data analysis indicated that this theme was manifested in the compositions written by the students of all the three groups. From frequency analysis, students in all the three groups allocated somehow identical percentage of their themes to this theme. This similarity could be attributed to the similarity in genre. The result of Chi-square analysis showed significant difference between the three groups regarding their use of marked theme. This difference could suggest the effect of academic experience on students writing. In this study senior students used this theme more than other two groups. These students may know, as stated by Gosden (1992), that using marked theme means bringing some elements into the theme position which commonly have the function of textual organization. These elements may signal changes and turns in real-world and discourse circumstances. It is by these elements that we could recognize the rhetorical structure of the text.

On the other hand lack of academic experience may cause sophomore students to use this theme in small number comparing to other two groups. These students by putting the subject in the theme position wanted to make sure that their sentences are grammatically correct.

The result of the present study will benefit the EFL students and English language instructors in general and English language students in composition writings in particular. Theme awareness, in this case marked theme, can help students to create textual piece of writing. The present study can also help the readers to comprehend the text. The readers need to be aware of the rhetorical structure through which the writer is presenting the information in the text. Generally speaking, this awareness can guide readers through the logical path constructed by the writers to comprehend the subsequent segment and help them to understand the text better. 
We would like to express our gratitude to our best friend Mr. Khedri, who has provided so much help and kindness in conducting this research.

\section{REFERENCES}

[1] Belmonte, I. A. , \& McCabe, A. M. (1998). Theme-rheme patterns in L2 writing. Retrieved May 30, 2007, from: http://www.ucm.es/BUCM/edu/articulos/DIDA.pdf

[2] Brown, G. , \& Yule, G. (1983). Discourse analysis. Cambridge: Cambridge University Press.

[3] Coffin, C. \& Hewings, A. (2005). IELTS as preparation for tertiary writing: Distinctive interpersonal and textual strategies. In L. J. Ravelli, \& R. A Ellis, (Eds.). Analysing academic writing (pp. 153 - 171). London: Continum.

[4] Davidse, K. (1987). M.A.K. Halliday's functional grammar and the Prague School. In R. Dirven. , \& V. Fried (Eds.), Functionalism in linguistics (pp. 39-79). Amsterdam: John Benjamins.

[5] Ebrahimi, S. F. (2008). Thematic organization and thematic progression in Iranian EFL composition writing: Implication in teaching writing skill. Unpublished thesis. Ahvaz: Islamic Azad University, Science and Research Branch Press.

[6] Fowler, W. S. \& Coe, N. (1976). Nelson English language texts. London: Britain.

[7] Fries, P. H. (1992). Theme and new in written English. Retrieved April 18, 2007, from http:// Google/Functional Approach/ Section 17.htm.

[8] Fries, P. H. (1994). On theme, rheme and discourse goals. In M. Coulthard (Ed.), Advances in written text analysis (pp. 229249). London: Routledge.

[9] Gabrielatos, C. (2002). EFL Writing: Product and process. Retrieved June 10, 2010, from: http:// www.gabrielatos.com/EFLWriting.htm

[10] Ghadessy, M. (1995). Thematic development and its relationship to registers and genres. In M. Ghadessy (Ed.), Thematic development in English text (pp. 129-146). London: Pinter.

[11] Ghadessy, M. (1999). Thematic organization in academic article abstracts. Estudios Ingleses de la Universidad Complutense, 7 , 141-161.

[12] Gosden, H. (1992). Discourse functions of marked theme in scientific research articles. Journal of English for Specific Purposes, 11, pp. 207-224.

[13] Halliday, M. A. k. (1985). An introduction to functional grammar. London: Edward Arnold.

[14] Halliday, M. A. k. (1994). An introduction to functional grammar. London: Edward Arnold.

[15] Halliday, M. A. k. , \& Hasan, R. (1976). Cohesion in English. London: Longman.

[16] Halliday, M. A. k. , \& Matthiessen, C. (1997). Systemic functional grammar: A first step into the theory. Retrieved April 18, 2007, from: http://SFG intro (peng chapter) New.htm

[17] Jalilifar, A.R. (2010). The status of theme in Applied Linguistics Articles. The Asian ESP Journal, 6. 2, pp. 7-39 .

[18] Jalilifar, A.R. \& Khedri, M (2011). thematic development in English and translated academic text. In A.R. Jalilifar, \& E. Abdollahzadah, (eds.), Academic research genre in Asian context (pp. 335 - 364). Ahwaz: Shahid Chamran University Press.

[19] Lores, R. (2004). On RA abstracts: From rhetorical structure to thematic organization. Journal of English for Specific Purposes, 23, 280-302.

[20] Martin, J. R. , \& Rose, D. (2007). Gener relations: Mapping culture. London: Equinox.

[21] Martinez, I. A. (2003). Aspects of theme in the method and discussion sections of biology journal article in English. Journal of English for Academic Purpose, 2, 103-123.

[22] Matthiessen, C. (2004). Descriptive motifs and generalizations. In A. Caffarel. , J. R. Martin. , \& C. Matthiessen (Eds.), Language functional perspective (pp. 537-673). Amsterdam: John Benjamins.

[23] McCabe, A. M. (1999). Theme and thematic patterns in Spanish and English history texts. Retrieved July 09, 2007, from: http: // www. wagsoft.com/systemics/archive/McCabe.phd

[24] North, S (2005). Disciplinary variation in the use of theme in undergraduate essays. Journal of Applied Linguistics, 26 (3), 431 452.

[25] Ping, A. L. (2003). Theme as constructing force. Journal of Language and Linguistics, 2 (2), 1-14.

[26] Ventola, E. (1995). Thematic development and translation. In M. Ghadessy (Ed.), Thematic development in English text (pp. 85-104). London: Pinter.

[27] Wang, L. (2007). Theme and rheme in the thematic organization of text: Implication for teaching academic writing. Asian EFL Journal, 9 (1), 1-11.

[28] Whittaker, R. (1995). Theme, process and the relation of meaning in academic articles. In M. Ghadessy (Ed.), Thematic development in English text (pp. 105-128). London: Pinter.

Seyed Foad Ebrahimi was born in Abadan (Islamic Republic of Iran) in 1981. In 2008, he earned his M.A in Teaching English as Foreign Language from Islamic Azad University. His primary concern in his M.A thesis was Systemic Functional Linguistics. He is now a Ph.D. student at University Putra Malaysia (UPM). He has presented four papers in two international conferences in 2011, he as well published two articles in Education Quest: International Journal of education and applied social sciences.

Seyed Jamal Ebrahimi was born in Abadan (Islamic Republic of Iran) in 1971. In 2004, he earned his M.A in Teaching English as Foreign Language from Islamic Azad University. His primary concern in his M.A thesis was Bilingual studies. He is now a Ph.D. student at University Technology Malaysia (UTM). He has presented a paper in two international conferences in 2011, he as well published an articles in Education Quest: International Journal of education and applied social sciences. 